Original Research Paper

\title{
DISTRIBUTION AND SURVIVAL OF MEGAPODIUS REINWARDT FOR ECOTOURISM CONTRIBUTING ON MOYO ISLAND
}

\author{
M. Yamin ${ }^{1 *}$, Khairuddin ${ }^{1}$ \\ ${ }^{1}$ Biology Education Study Programme, Faculty of Teacher Training and Education, University of Mataram, \\ Indonesia
}

Article history

Received: September $10^{\text {st }}, 2018$

Revised: October $4^{\text {st }}, 2018$

Accepted: November $4^{\text {st }}, 2018$

Published: November $21^{\text {st }}, 2018$

*Corresponding Author:

\section{Yamin,}

Biology Education Study

Programme, Faculty of Teacher

Training and Education, University of Mataram;

Email:

muhammadyamin.fkip@gmail.com

\begin{abstract}
Megapodius reinwardt is one of the protected bird species in Indonesia. The protection toward megapodius reinwardt because of limited distribution, high economic value, has an important ecological role, has a unique, difficult breeding in captivity, the population is drastically shrinking and getting scarce.Based on this condition, the purpose of this research is to know population distribution mapping, active nest study, disturber population in order to support the atraction tourism and conservation of Megapodius reinwardt at Moyo island. Survey and observation are used to collect research data. The distributionofMegapodius reinwardt is spread around Moyo Island. The nest is located in the forest and it build by heap of soil with high 150 centimeters until 175 centimeters and diameters up to $825 \mathrm{~cm}$. The location of Megapodius reinwardtnests are mostly in secundary forest than primary forest and savana at $25 \mathrm{~m}$ above sea level. The rproduct moment correlation coefficient $(\mathrm{r}=0,484)$ conclude that, Varanus $\mathrm{sp}$, Sus barbatus, Prinodon linsang, Haliastur indus, Microhierax fringillarius, and human as predators are not significant to influence the nests and population of Megapodius reinwardtdecrease. So the existence of Megapodius reinwardtmanagement is needed according to in-situ cencervation on Moyo Island forEcotourism Contributing
\end{abstract}

Keywords: Ecotourism, distribution, Megapodius, survival.

\section{Introduction}

Megapodius reinwardt is one of the bird species that is protected based on the Indonesia's Law No.5 of 1990 and the Decree of the Minister of Forestry no. 301 / Kpts- II / 1991. The protection toward megapodius reinwardt because of limited distribution, high economic value, has an important ecological role, has a unique large size of eggs five to six times that other birdshave, no incubating the eggs or burrow nesters and rely on geothermal heat for incubation or solar-heated soil, not keeping and watching for their children's survival or they provide no parental care, either before or after hatching, difficult breeding in captivity, the population is drastically shrinking and getting scarce. (BKSDA, 2008., Goth and Vogel, 2004., Harris, Birks, and Leache, 2014). At least, half of all bird families are threatened with extinction due to habitat loss, high predation of eggs and their children by lizards, wild boars and humans and lack of biological information (BKSDA, 2008) . Furthermore Jessop et al. 2006 reported the predation of bird's nest by lizard and wild boar reached $17 \%$.

In West Nusa Tenggara, megapodius reinwardt is a bird that has high economic value, because the meat and eggs are popular for many people. In this situation, it is not surprising that the hunt for this bird species is increasing, with the result as triggering a drastic decreased of its population. If the action is left unchecked and there is no conservation effort, then megapodiusreinwardt will be extinct in the short time. In addition habitats have drastically changed in the last few decades due to agricultural intensification and rural depopulation (Granados, et, al. 2018). The threat of extinction of Megapodiusreinwardt is greater because it includes birds that are difficult to breed in captivity. Breeding efforts till nowdays have not been successful. Protected areas, are essential for 
biodiversity conservation because they often provide habitats protection and conservation fot hunting, especially for threatened and endangered species (Aynalem and Afework, 2018)

The ineffectiveness of breeding efforts can be caused by various factors, such as the discrepancy of the species, the pouch, and the chemical composition of the nutritional value of the food in captivity with the natural habitat, nesting material, insufficient cage size to perform certain motion (behavior) for mating, and the composition of habitat elements in nature, especially vegetation elements, with those in artificial habitats in captivity. Vegetation is habitat various species of wild animal as primate, reptile and birds. Beside that, vegetattion is habitat the most important element, especially in bird habitat, because it serves as a source of feed, shelter, restplace and a place for breeding. Biodiversity positively relates with the provisioning of ecosystem services and preserving areas (Nugroho Edi Kartijono, et all. 2010., Nathalie, et. al, 2018 ). For the successful of Megapodius reinwardt breeding efforts which is increasingly rare, the accurate and comprehensive data and information is required on the aspects of bird biology especially in: behavior, resource use, nest, chemical contents and compositions, and the food nutritional value, and reproductive biology in natural habitats. These factors are very influential in vitality, endurance, and survival. Therefore, research on that problem is urgent as a conservation effort, well on in-situ and ex-situ; in order we do not lose the biodiversity resources of the region.

As problem described in the background, this study aims to study thoroughly and accurately about population, distribution, habitat characteristics, daily activities, breeding, survival and food in natural habitats. Inovation of this research is not only very beneficial for the management and conservation of Megapodius reinwardt on in situ and ex-situ, its also contributes to the refinement of research method of identification or study of wildlife species, especially birds that have been done by survey/ observation method. In addition, it is also conducted for the development of science, as an effort to introduce the region's unique biodiversity and the Indonesian Nation to attract tourists.

\section{Material and Methods}

This research was conducted in Moyo Island, because the bird population naturally can be found on the island in West Nusa Tenggara. his research was conducted in the field on 2017, directed to study a number of biology aspects of Megapodius reinwardt. Biological aspects studied cover the geographical position of the point of distribution of active nests, the characteristics of the nest, predators, disease and survival in their natural habitat. The data was collected by a survey and direct identification in the morning at 06.00 am until 10.00 am and in the afternoon at 16.00 until 18.00. Positioning the nest is done by using GPS (Global Positioning System). The coordinate points in the GPS were recorded South Latitude (LS) and East Longitude (BT) (Juwana and Romimohtarto 1999). In addition, the measurement of the mound diameter of the soil used as a nest, height, soil type, mass, hole nest diameter, temperature and altitude from sea level as well as the recording of the nest and surrounding vegetation. The nest materials data were identified and analyzed based on the type and composition of the material. The soil type data was analyzed in Soil Laboratory of Mataram University.

The data collection were analyzed qualitatively by descripting each aspect. Quantitative analysis was conducted on the vegetation around the nest including the species diversity index $(\mathrm{H})$, density $(\mathrm{K})$, dominance (D) and the Importance Value Index (IVI). In addition, the analysis of the effect of various factors on the Megapodius reinwardt population in Moyo Island with F-test and analysis of the tendency of nesting site selection and the pattern of pairing with the bird with Chi-Square Test.

\section{Results and Discussion}

\section{Distribution Population of Megapodius reinwardt on Moyo Island.}

The island is geographically located at 80 . 9'.36 " South Latitude (LS) up to 80. 23'.19 ' ' LS and 1170.27'43 ' East Longitude (BT) up to 1170.35'42 '" BT (BKSDA, NTB 2017). The island has beautiful scenery and a number of interesting tourism objects including Mata Jitu waterfalls, Caves and a variety of typical wildlife species and limited distribution like Megapodius reinwardt, Cacatua sulpurea, Philemon 
buceriodes, Cervus timorensis De Blan Valla and Sus barbatus. Approximately $75 \%$ of its area is a protected area, has 77 types of vegetation with two types of communities namely forest communities and savannah grassland communities (Mukhtar, 1996). The forest community covers 22,250 hectares, savannah around 2,000 hectares (PHPA Team, 1988). The remaining 5,750 hectares are coconut and moor plantations in the north, residential areas, and hotels; however the extent of each is not known for certain, because the purpose of the study only wanted to know the distribution of population, graduation and perceptions of local residents of Moyo Island against the existence of Megapodius reinwardt.

The population distribution data of Megapodius reinwardt conducted on the existence of the bird's nest active colonies in the form of mounds of soil in the forest as high as about 1.5 to 1.75 meters with diameter of up to eight meters. The other reseach report that, the nest of Megapodius reinwardt in Rinca island was found $0.4-0.9 \mathrm{~m}$ hight with diameter $5,11-9,30 \mathrm{~m}$ (Rosdalima Panggur, 2008). Furthermore, Mujdalifah at.al. (2015) found 0.5 -1 m hight with diameter $3-4.5 \mathrm{~m}$. Rosdalimah (2015) reported that, the nest high and diameter differenciation were because of using together between Megapodius reinwardtand Komodo dragon colonies, but in this research was not found the sharing net colonies with the other animals. The other factors were because of soil structure dan open space of nest colonies in the forest. Documenting of the existence of Megapodius reinwardt nest colony because it is a terrestrial bird that almost all day activities are above ground level besides took refuge from predators and sleep at night on the trees.

Based on topography of Moyo Island which is hilly and mountainous, mostly in the form of forest, sea, the existence of human settlements and the accessibility is still relatively difficult and expensive, in this study the data collection about population distribution Megapodius reinwardt only conducted in the western part of the South Island of the five locations: in the area of Labuhan Haji hamlet, Berang Sedo hamlet, Ai Manis hamlet, Ai Dara and Tanjung Pasir. The description of Megapodius reinwardt's nest and its spreading on Moyo Island 2017 is presented below.
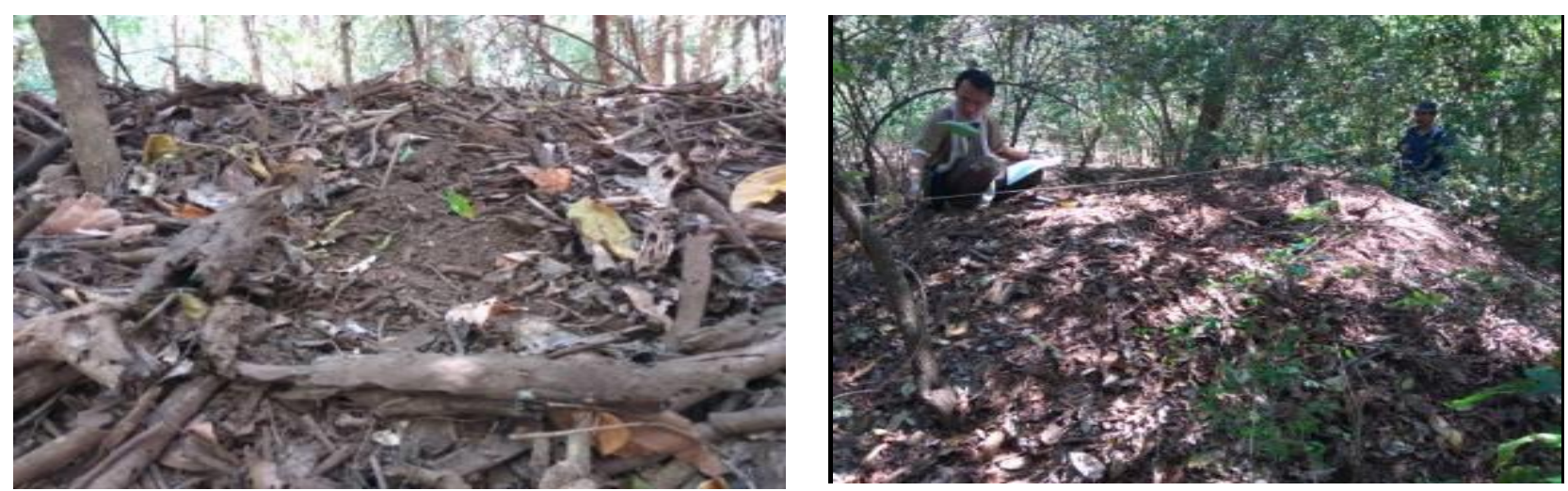

Figure 1 Profile of Megapodius reinwardt nest on Moyo Island 2017

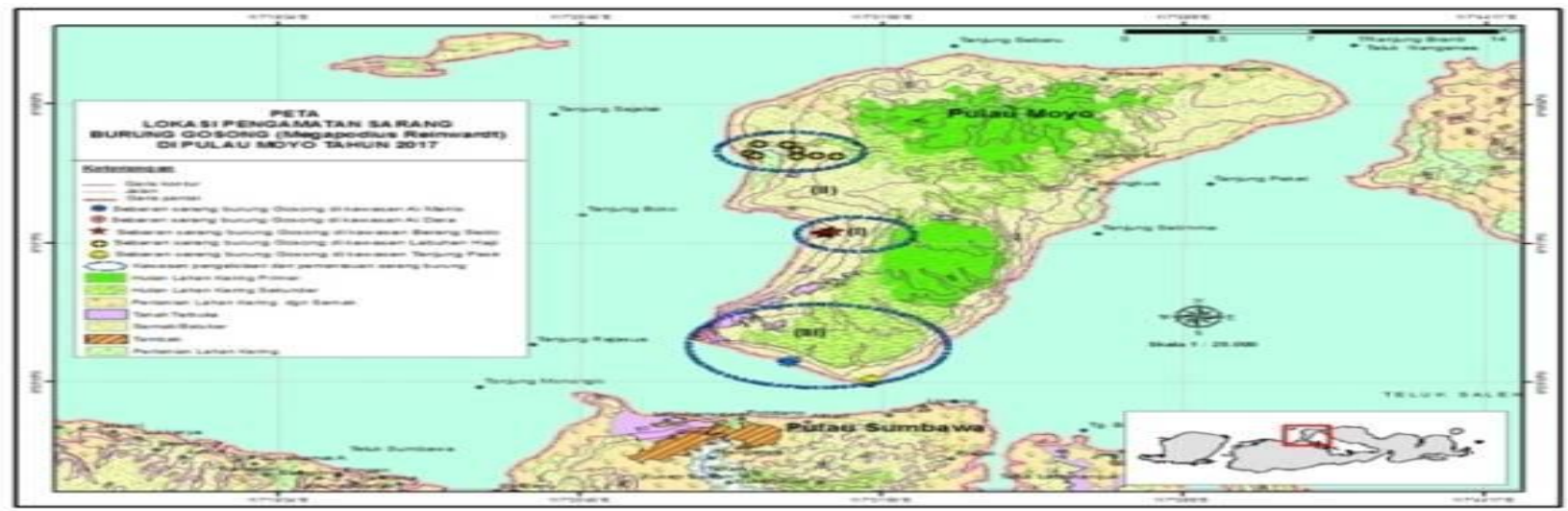

Figure 2 Observing Location of Megapodius reinwardt distribution on Moyo Island 2017 
From the picture above, it can be seen the existence of Megapodius reinwardt in Moyo Island spread from Tanjung Pasir in the South to Labuhan Haji in the Southwest. The existence of the nest was found mostly in the secondary forest in Labuhan Haji as many as 8 colonies and 57 active holes nest, then in Berang Sedo 6 colonies and 45 active holes nest, in Ai Manis, Ai Dara and Tanjung Pasir Each of the 2 colonies and 13 active holes nest. Megapodius reinwardt nest colony in the form of a mound entirely was found in the forest.

The diversity of species and density of vegetation around the colony nest in every location of the observations of 17 species to 22 species. The diversity of primary forest vegetation types in Tanjung Pasir 22 species with density of 302 individuals, Ai Dara savannah 17 species with density of 58 individuals, and in secondary forests Labuhan Haji 21 species with density of 136 individuals (Table 4). From these description, the diversity of vegetation was unrelated to the existance of Megapodius reinwardt nests in a habitat.Megapodius reinwardt like to live in wide apart vegetation habitat and open field. The vegetations were osed by Megapodius reinwardt to protect, taking rest dn sleept. Nugroho (2010), reported that the strafication of vegetation relateted to roost, nesting, waiting prey, resting and protection. Megapodius reinwardt daily activities almost on soil surface, except their protection from predator and slept in the night on the trees. Incompatibility with Kiky Arysta (2015), He stated that the family of Megapodius used the highest vegetation density to protect theirself from predator. The differenciation of this behavior was predicted because of significantly humans disturbed (87.9 \%) in Parigi Moutong, Central Sulawesi. Eventhough Megapodius in Moyo Island were secure relatively.

The species diversity index $(\mathrm{H})$ of vegetation around all nest colonies ranges from 2.24 to 2.53 . The highest species diversity index is found in the secondary forest of Labuhan Haji, and the lowest species diversity index is found in Tanjung Pasir primary forest. The dominant vegetation type in each location of observation is Tanjung Pasir primary forest from 22 species of vegetation in sequence: Merremia sp. INP 92\%, Sterculia oblongata INP $=48 \%$, Phyllanthus emblica INP 25\%, Saripellus asper INP 20\%, Aphanamixis grandiflora INP 15\%, T. Indica INP $=14 \%$. Sixteen other tree species have an INP of less than 9\% (Table 3). The dominant vegetation type in secondary forest of Labuhan Haji Pulau Moyo of 21 species in sequence: Crotolaria straiata INP $=59 \%$, Alstonia spectabilis $I N P=$ $38 \%$, Alstonia anguisteloba INP $=36 \%$, Schoutenia ovata $=16 \%$, Alstonia scholaris INP $=$ $15 \%$, Lagerstroemia speciosa INP $=10 \%$. Fifteen other tree species have an INP of less than $10 \%$ Types of dominant vegetation in the savanna station sequentially: Merremia sp INP $86.06 \%, T$. Indica INP $=39.59 \%$, A. Anguisteloba INP $=$ $35.52 \%$, P. Javanicum INP $=25.22 \%$, S .perper $I N P=21.67 \%$, Schoutenia ovata INP $=17.01 \%$, A. Lebbek INP $=10.92 \%$, and A. Spectabilis INP $=10,7 \%$. Six other tree species have an INP of less than $10 \%$ (Table 4).

From the data above, it is assumed that the presence of Megapodius reinwardt in a place is not related to the diversity and the dominance of the vegetation type, but it israther determined by the availability of feed ingredients and density of trees. This is in line with the report (Yamin \& Laksmiwati, 2012) that the presence of Megapodius reinwardt in a habitat type is not associated with a profile, the number of individuals, and the diversity of tree species, but more determined by the availability of feed ingredients, the density of the trees and the high places from the sea level. In line with this (Kiky Arista et al., 2015) reported that the area of forest and vegetation density did not significantly affect the causes of population declines of Maleo bird. Widodo (2015), reported that fosetry birds distribution just in the jungles and gardens, because of foods avialibilities, like fruits and insects. Here presented the results of the census presence of Megapodius reinwardt nest colony on Moyo Island.

Table 1. Nest Collony of Megapodius reinwardton Moyo Island in July 2017

\begin{tabular}{lllll}
\hline Location & $\Sigma$ Nest Colony & Forest Type & Secondary & Savannah \\
\hline Labuhan Haji & 8 & Primer & 8 & 0 \\
BerangSedo & 6 & 0 & 4 & 2 \\
Ai Manis & 2 & 0 & 0 & 0 \\
\hline
\end{tabular}


Yamin et al, Jurnal Bologi Tropis, 18 (02) : 189 - 199 DOI: http://dx.doi.org/10.29303/ibt.v18i2.931

\begin{tabular}{lllll}
\hline Location & \multicolumn{1}{c}{} & & \\
& & Forest Type & \\
Primer & Secondary & Savannah \\
\hline Ai Dara & 2 & 2 & 0 & 0 \\
TanjungPasir & 2 & 2 & 0 & 0 \\
Total & 20 & 6 & 12 & 2 \\
Khi-kuadrat Test $\left(\mathrm{X}^{2}\right) \quad=7,19$ & & & \\
$\left(\mathrm{X}^{2}\right) \square 0,05$ for $\mathrm{v}=2$ degrees free $=5,99$ & & & \\
\hline
\end{tabular}

The results of the analysis of Khi-square test (X2) to nest colony site selection pattern Megapodius reinwardt in its habitat on Moyo Island obtained Khi-square calculate of 7.19 while the value of Khi-squared table at $\alpha=5 \%(0.05)$ and $\mathrm{dv}=2$ is 5,99. This means that Megapodiusreinwardt hich the Megapodius reinwardt nest colony on Moyo Island in July 2017 are presented in the following table.

Table 2. Distribution, Number, Diameter, High-nest, Altitude and Soil Type Megapodius reinwardt nest on Moyo Island in July 2017.

\begin{tabular}{|c|c|c|c|c|c|c|c|}
\hline \multirow{2}{*}{$\begin{array}{l}\text { Nest } \\
\text { Colony }\end{array}$} & \multirow{2}{*}{$\begin{array}{l}\text { Nest Koordinat } \\
\text { Meridian }\end{array}$} & \multirow[b]{2}{*}{ Longitudinal } & \multicolumn{4}{|c|}{ Colony Nest Size (meters) } & \multirow[t]{2}{*}{ Soil } \\
\hline & & & $\begin{array}{l}\varnothing \\
\text { Nest }\end{array}$ & High & Hole Nest & $\begin{array}{l}\text { Above water } \\
\text { sea }\end{array}$ & \\
\hline$\overline{1 *}$ & $117^{\mathrm{O}} 31^{\prime} 38.33^{\prime \prime}$ & $8^{\mathrm{O}} 23^{\prime} 15.07$, & 4 & 0.7 & 9 & 5 & Topsoil \\
\hline $2 *$ & $117^{\mathrm{O}} 31^{\prime} 43.12 ”$ & $8^{\mathrm{O}} 23^{\prime} 07.76^{\prime}$ & 4.3 & 1.2 & 4 & 5 & Sandy \\
\hline $3^{\#}$ & $117^{\mathrm{O}} 29^{\prime} 58.03^{\prime \prime}$ & $8^{\mathrm{O}} 22^{\prime} 18.23^{\prime}$ & 8 & 1.1 & 8 & 5 & Sandy \\
\hline $4^{\#}$ & $117^{\mathrm{O}} 30^{\prime} 2.70^{\prime \prime}$ & $8^{\mathrm{O}} 22^{\prime} 20.31^{\prime \prime}$ & 4 & 7.5 & 8 & 10 & Sandy \\
\hline $5 \%$ & $117^{\mathrm{O}} 28^{\prime} 21.03^{\prime \prime}$ & $8^{\mathrm{o}} 21{ }^{\prime} 31.31 '$ & 5 & 1.5 & 7 & 10 & Ca deposits \\
\hline $6 "$ & $117^{\mathrm{o}} 28.12 .36^{\prime \prime}$ & $8^{\mathrm{O}} 21^{\prime} 12.29{ }^{\prime}$ & 4.7 & 1.5 & 6 & 5 & Ca deposits \\
\hline $7^{\#}$ & $117^{\mathrm{o}} 30^{\prime} 43.51^{\prime \prime}$ & $8^{\mathrm{O}} 16^{\prime} 36.02$, & 3.7 & 0.9 & 6 & 25 & Topsoil \\
\hline $8^{\#}$ & $117^{\mathrm{O}} 30^{\prime} 45.07^{\prime \prime}$ & $8^{\mathrm{o}} 16^{\prime} 35.64^{\prime \prime}$ & 5 & 0.7 & 8 & 30 & Topsoil \\
\hline $9^{\#}$ & $117^{\mathrm{o}} 30^{\prime} 48.50^{\prime \prime}$ & $8^{\mathrm{O}} 16^{\prime} 36.52^{\prime}$ & 6.8 & 1.53 & 7 & 30 & Topsoil \\
\hline $10^{\#}$ & $117^{\mathrm{O}} 30^{\prime} 50.40^{\prime \prime}$ & $8^{\mathrm{o}} 16^{\prime} 33.06^{\prime}$ & 6 & 1.55 & 6 & 28 & Topsoil \\
\hline $11^{\#}$ & $117^{\mathrm{O}} 30^{\prime} 55.05^{\prime \prime}$ & $8^{\mathrm{o}} 16^{\prime} 31.00 "$ & 4.7 & 0.8 & 7 & 35 & Topsoil \\
\hline $12^{\#}$ & $117^{\mathrm{O}} 30^{\prime} 57.23^{\prime \prime}$ & $8^{\mathrm{o}} 16^{\prime} 31.47^{\prime \prime}$ & 5.6 & 1.2 & 11 & 50 & Topsoil \\
\hline $13^{\#}$ & $117^{0} 29^{\prime} 13,32^{\prime \prime}$ & $08^{0} 15^{\prime} 15,9 "$ & 7.5 & 1.5 & 7 & 60 & Ca deposits $r$ \\
\hline $14^{\#}$ & $117^{0} 299^{\prime} 009 ”$ & $08^{0} 15^{\prime} 41,46^{\prime \prime}$ & 8 & 1.75 & 7 & 65 & Topsoil \\
\hline $15^{\#}$ & $117^{0} .29^{\prime} 46,7^{\prime \prime}$ & $08^{0} 15^{\prime} 17,3 ”$ & 7 & 1.7 & 8 & 50 & Ca deposits \\
\hline $16^{\#}$ & $117^{0} 30^{\prime} 58,6^{\prime \prime}$ & $08^{0} 15^{\prime} 32,4 ”$ & 8 & 2 & 11 & 40 & Topsoil \\
\hline $17^{\#}$ & $117^{0} .30^{\prime} 59,3 "$ & $08^{0} 15^{\prime} 48,7^{\prime \prime}$ & 7.3 & 1.7 & 7 & 35 & Topsoil \\
\hline $18^{\#}$ & $117^{0} 30^{\prime} 09,08^{\prime \prime}$ & $08^{0} 5^{\prime} 45,56^{\prime \prime}$ & 7 & 1.5 & 6 & 40 & Topsoil \\
\hline $19^{\#}$ & $117^{0} .31^{\prime} 23,2 ”$ & $08^{0} 16^{\prime} 46,5^{\prime \prime}$ & 7.25 & 1.65 & 5 & 30 & Topsoil \\
\hline $20^{\#}$ & $117^{0} 31^{\prime} 48,6 "$ & $08^{0} 16^{\prime} 48,5 "$ & 7.5 & 1.6 & 6 & 10 & Topsoil \\
\hline Sum & & & 121.35 & 33.58 & 144 & 568 & - \\
\hline Average & & & 5.15 & 1.68 & 7.25 & 28 & \\
\hline
\end{tabular}

Data Sources: Survey Results of Researcher Team of Mental Nest Active Megapodius 2017 \# = Secondary Forest; "= Savana; * = Primary forest / protected area significantly (likes) a nested site in a secondary forest area rather than in the forest area of primary one and savannah.

The coordinates of the nest colony footprint, the number of holes in each colony, the diameter, the height of the colony, the altitude of the sea level and the type of soil in $w$ 
From Table 1 above, each colony nest has 4 to 11 nests with a diameter between 3.7 meters to 8 meters and height nest between 0.7 and 2 meters. Megapodius reinwardt looks like the location of the colony nest of secondary forests than in primary forests and savannah. From the survey conducted by the research team in the five locations above, it was found 20 pieces of active nest colonies. From 20 colonies active nest recorded 8 colonies with 57 nests in the secondary forest in the area of Labuahn Haji at an altitude of \pm 10 to 60 meters above sea level, and 6 colonies with 45 nests in the primary forest Berang Sedo at an altitude of \pm 25 to 50 meters above sea level, while in savanna di Ai Dara and Ai Manis each found 2 colonies degan 13 nests at an altitude of \pm 5 to 10 meters above sea level and primary forest Tanjung each found 2 colonies with 13 active nest at an altitude of $\pm 5 \mathrm{dpl}$. (Appendix 2 and 3). This is understandable because Megapodius reinwardt is a teristerial bird whicheats insects, grains, worms and fruit flesh (Yamin \& Laksmiwati, 2012). Subsequently reported that the presence of Megapodius reinwardt in a habitat type is not associated with the profile, the number of individuals, and the diversity of tree species, but rather is determined by the availability of feed ingredients, the density of the trees and the high places from the sea level. Megapodius reinwardt prefers the plantation area rather than the forest area and the savannah (Yamin \& Laksmiwati 2012).

The large number of Megapodius reinwardt nest colonies was found in the Labuhan Haji areas because the area is an agricultural area that provides relatively more feed, less density of the tree and its location is relatively higher above sea level than Berang Sedo, Ai Dara, Ai Manis and Tanjung Pasir which has average of 45 meters above sea level, while the altitude of places in $\mathrm{Ai}$ Manis and Tanjung Pasir an average of 5 meters above sea level. Secondary forest and bush areas around agricultural areas besides providing more food in the form of insects, termites, insects and worms than primary forest or savannah is also very well be used for shelter from predators. Habitats that have too high trees restricting Megapodius reinwardt for hunting because obstructed by tree branches when hunting for insects. Instead, the lavish locations are also less favorable, because Megapodiusreinwardt less provide safety from predators when hunting. If there is no tree no shelter when pursued by a predator. Therefore savannah habitats around the area Ai Manis and Ai Dara is also less favorable than the secondary forests in the areas of Labuhan Haji and Berang Sedo. In this regard, according to the Orions of 1969 (see Sunaryan 1999) stated that the presence of birds in a place is influenced by several factors such as the abundance of epiphytic plants, fruits, openness of the floor, and the composition of plant species. Most insectivorous birds, for example the Dicruridae and Oriolidae liked the open part of the forest, edge forest areas, plantations and gardens (Beehler, et al., 1986; MacKinnon, et al., 1992). In agreement with this Monk et al.(1997) stated that each species is highly dependent on environmental factors in the habitat, such as vegetation, water, and climate. Here is presented the results of the calculation of Diversity Index ( $\left.\mathrm{H}^{\prime}\right)$, Uniformity index $(\mathrm{E})$, Density $(\mathrm{K})$, Frequency, $(\mathrm{F})$ Dominant type in each location Megapodiusreinwardt nest colony on Moyo Island in July 2017.

Table 3. Diversity Index (H '), Uniformity Index (E), Density (K), Frequency, (F) Vegetation Dominant at each location of Megapodius reinwardt nest colony in July 2017.

\begin{tabular}{llllll}
\hline Location & H' & E & K & F & Community \\
\hline Primer Forest & 2,24 & 0,72 & 302 & 7 & Merremia sp. S. oblongata, S. oleosa. \\
Secondary Forest & 2,53 & 0,89 & 136 & 9 & C. pentandra, P.javanicum, Bauhinia sp \\
Savannah & 2,50 & 0,95 & 58 & 5 & Merremia sp., T. indica, A.anguisteloba \\
\hline
\end{tabular}

Information $: \mathrm{H}=$ DiversityIndex, $\mathrm{E}=$ Uniformity Index; $\mathrm{K}=$ Density of tree / hectare, $\mathrm{F}=$ Frequency of attandance of Megapodius reinwardt

The diversity of vegetation is not expected to affect the existence Megapodius reinwardt in a location. Similarly, its diversity (Appendix 3), it was seen in the encounter of Megapodius reinwardt most colonies of the secondary forest in Labuhan Haji area with a diversity of 21 species of 
vegetation, but there were eight colonies with 57 active nests, whereas in the location of primary forest in Tanjung Pasir area where there were 22 species of vegetation found 2 colonies with 13 active nests. From these data it can be concluded that the existence of Megapodius reinwardt nest colony is not determined by the variety and diversity of vegetation type, but rather is determined by the availability of feed ingredients.

\section{Population and Activity of Megapodius reinwardt in Natural Habitat of Moyo Island}

The exploration and census conducted on the Megapodius reinwardt population for three days in the area of about 750 hectares at Taman
Buru Pulau Moyo, found 29 birds. The largest number of individuals found in the plantation area around Berang Sedo and Labuan Aji villages, which are 13 birds, then 9 birds in the edge of the forest Ai Manis, and 7 birds in savanna around $\mathrm{Ai}$ Dara and Tanjung Pasir. In the activity, from the number of 29 birds, there were found 15 birds in pairs, 8 tails birdssolitary, and 6 birds in group. The result of Khi-square Test $\left(X^{2}\right)$ to patternthe grouping showed the pairwise pattern selection significantly more than the solitary pattern and the group pattern (Table 4). Megapodius reinwardtalways in pair as long as their life. Maria (2008) predicted the solitary of Megapodius reinwardt was juvenile.

Table 4. The Result of Megapodius reinwardtPopulation census on Moyo Island in July, 2017

\begin{tabular}{llllll}
\hline Location & $\begin{array}{l}\text { The Area } \\
\text { (Hectare) }\end{array}$ & \multicolumn{2}{c}{ The number of individu Activity Pattern } \\
& \multicolumn{2}{l}{ Solitary } & Pairs & Group \\
\hline Plantation Area & 300 & 13 & 4 & 6 & 3 \\
The edge of forest & 240 & 9 & 2 & 4 & 3 \\
Savanna \& Primary forest & 210 & 7 & 2 & 5 & 0 \\
$\begin{array}{l}\text { Total } \\
\text { Chi-square Test }\left(\mathrm{X}^{2}\right)\end{array}$ & 750 & 29 & 8 & 15 & 6 \\
$\left(\mathrm{X}^{2}\right) \square 0,05$ for $\mathrm{v}=2$ & free degrees & $=24,75$ & & \\
\hline
\end{tabular}

The large number (13 birds) of Megapodiusreinwardt found in the plantation area around Labuan Aji Village is allegedly closely related to habitat floor openness factor. These factors affect the activity of this bird in the search for food. The plantation area provides relatively more food in the form of insects, termite worms and grains than other habitat types such as forests. In addition, the plantation area has relatively sufficient tree stands to shelter the birds from its various predators, so that overly open areas such as savannas are unpopular as are forests whose vegetation is too dense. The presence of Megapodius reinwardt in a habitat is not determined by dominant tree species, but is more influenced by the presence of reproductive species and phases of the plant as well as the openness of the habitat as a feeding ground.

In this regard, according to the Orions of 1969 (see Sunaryan 1999) states that the presence of birds in a place is influenced by several factors such as the abundance of epiphytic plants, fruits, floor openness, and plant species composition. Most insectivorous birds, such as the Dicruridae and Oriolidae, like the open forest, theedge forest, the plantation, and the park (Beehler, et al., 1986; MacKinnon, et al., 1992).

The large number of frequent visits of Megapodius reinwardt in the plantation area is caused by several factors such as the availability of enough insects and plants that provide their favorite foods. Plantation habitats are mainly used for feeding, as they provide relatively more seeds and more abundant insects. Related to this issue, Monk et al. (1997) said that each species is highly dependent on environmental factors in its habitat, such as vegetation, water, and climate.

The mealtime of Megapodius reinwardt looks more active in the morning 06.00 to 10.00 compared to the afternoon and at noonas well as inversely proportional to density of trees, except in the savanna habitat. This is because in morningtime Megapodius reinwardt is actively looking for seeds and insects, whereas the presence of insects is relatively more in places with lower tree density (relatively open) compared to the place where the trees are dense. Contrastly, in the afternoon, Megapodius reinwardt populations are more in habitats that have 
relatively high tree density, because by late afternoon the birds go back to sleep into the forest.

From the above findings, it is estimated that Megapodius reinwardt on Moyo Island mates and lodged around September to October, and begins at the beginning of the rainy season in November. According to Muhtar (1996), wet season on the island of Moyo starts from November to March. Related to this condition, observations of behavior before and during the Megapodius reinwardt mating season has not been done.

\section{Disturbance of Megapodius reinwardt Population on Moyo Island. \\ Megapodius reinwardt is one of the} protected bird species based on RI-Law No.5 of 1990 and Ministry of Forestry Decree No. $301 /$ Kpts-II / 199 and No. 882 / Kpts-II / 1992 and PP no. 7 of 1999 concerning Preservation of Plant and animal species. The protection of birds is done because of its unique, limited distribution, its important ecological role, its biological characteristic information is very small, it is difficult to breed in captivity and begin to be rare (PHPA, 1988; MacKinnon, et al. 2000). Megapodius reinwardt used to be found in Great Sunda on Kangean Island in East Java, but now is very rare, so in West Nusa Tenggara it is very rare, except in Moyo Island. The threat of extinction of birds is greater because it includes birds that are difficult to breed in captivity.

From the observation result on Moyo Island that the research team found, the main disturber of Megapodius reinwardt population was boar (Sus barbatus), lizard (Varanus sp.), Civet (Prinodon linsang), ground snake (Calloselasma rhodostoma) eagle (Haliastur indus), human, disease and their age. The population of predatory animals of Megapodiusreinwardt on Moyo Island is not known for sure, but it is thought to be relatively large in number, especially boars, weasels, lizards and snakes. This is understandable because about $75 \%$ of the island is a protected area and the area of Hunting Park is mainly for boars, cows (Bos javanicus) and deer (Cervus timorensis).

Boars search for worms and other ground animals around and on the Megapodiusreinwardtnestingcolony, thus they damage the bird's nest. This is understandable because the Megapodiusreinwardt nest colony and the surrounding soil are loose soils containing a lot of humus, so it is favored by worms and other types of soil animals. Megapodiusreinwardt population 196 isturbance by lizards, snakes and civets in addition to direct predation of birds also eat eggs on the nest. Megapodius reinwardt does not incubate the eggs and nourish the child so predation by the predator against the bird at a young age is thought to be quite high. Another disturbance is the taking of eggs and the destruction of nests by humans, especially near the settlements around Labuhan Haji and Berang Sedo hamlets. Other disturbencewere caused by disease and pathogen, but not known for sure. The following presents the factors of disruption of the population in the natural habitat of Moyo Island in 2017.

Table 4 Disturber Population of Megapodius reinwardt on Moyo Island in 2017

\begin{tabular}{lllllllll}
\hline Nest Location & Vegetation & $\sum$ Colony/ & \multicolumn{2}{l}{ Frequency of Interference } & & \\
& Density & Nest & Boar & Lizard & Weasel & Snake & Eagle & Human \\
\hline HP & 302 & $2 / 13$ & 2 & 1 & 2 & 1 & 0 & 1 \\
HS & 136 & $16 / 118$ & 8 & 4 & 6 & 2 & 2 & 3 \\
Savanna & 58 & $2 / 13$ & 4 & 2 & 3 & 1 & 1 & 1 \\
Total & $20 / 144$ & 14 & 7 & 11 & 4 & 3 & 5 \\
F Test $=2,029$ & & & & & & & \\
$(\mathrm{~F}) \propto=0,05$ for $\mathrm{v}=6$ free degrees $=2,60$ & & & & & & \\
$\mathrm{R}^{2}=0,484$
\end{tabular}


$\mathrm{F}$ test is used to determine the level of influence of the six independent variables together to the dependent variable with Hypothesis: Ho: b1 $=\mathrm{b} 2=\ldots=\mathrm{b} 6=0 ; \mathrm{H} 1$ : not all $\mathrm{bi} \neq 0$. Based on summary of output calculated with correlation coefficient (R), the extent of the relationship between the boar, lizard, civet, snake, eagle and humans against the causal factor of nest presence and Megapodiusreinwardt population decline was 0.484. This means that the six factors together influence $48.4 \%$ of the existence of the nest and Megapodius reinwardt population decline in Moyo Island and $51.6 \%$ due to the influence of other factors not stated in the variable. The result of analysts influence the significance of the above six disturbing factors at the level of significance of $5 \%$ (0.05) obtained price $F$ count $=2.029 \leq$ from $F$ table $=2.60$ means that six factors (pigs, lizards, weasels, snakes, eagles and humans) do not significantly affect the presence of nests and Megapodius reinwardt population decline in Moyo Island. Related to thi aspect, Arista, et.al (2015) stated that the humans were influence the decreasing of Maleo population significantly in Sausu Piore village. They sold the eggs as high simbol of their own status.

The disturbance of the Megapodius reinwardt population on Moyo Island is still within the limits of tolerance. This is understandable because Moyo Island is a conservation area that is about $75 \%$ of its area is a protected area. T-test results partially to the six disturbing factors Megapodius reinwardt population on the island of Moyo known from the most frequent successive of boars, weasels, lizards, humans, snakes and eagles.

\section{Conclusion}

From the study and discussion above it is concluded that (1) Megapodiusreinwardtr populations are scattered throughout the mainland of Moyo Island, especially around Labuhan Haji, Berang Sedo, Ai Manis, Ai Dara and Tanjung Pasir; (2) Megapodiusreinwardt likes to nest in secondary forest areas rather than in primary forests and savannahs collectively between five and a dozen parent tails / nest colonies; (3) Megapodiusreinwardt daily activities such as feeding, playing, and resting preferly in pairs rather than clusters and solitary; (4) The disturbing Megapodiusreinwardt population on Moyo Island is boar (Sus barbatus), monitor lizard (Varanus sp.), Civet (Prinodon linsang), snake soil (Calloselasmarhodostoma) eagle (Haliastur indus), and human but their influence on nest existence and bird population was not significant.

\section{Suggestion}

Megapodius reinwardt management is needed according to in-situ cencervation on Moyo Island forEcotourism Contributing.

\section{Acknowledgement}

The authors are thankful to the Directorate General of Strengthening Research and Development, Directorate of Research and Community Service, Ministry of Research, Technology and Higher Education of Indonesia for providing the funding for carrying out this study. The authors would also like to thank Dr. Abdul Syukur, M. Si.for constructive criticism and comments during the preparation of this article.

\section{Author's Contributions}

M. Yamin: Conducted all experiments, data analysis and preparation of the draft manuscript. Haeruddin, Andra Ade Riyanto and Padusung: Advised research design, organized the manuscript's structures and edited the manuscript.

\section{References}

Alikodra, H. S. 1997. Pengelolaan habitat satwa liar dalam rangka mempertahankan keanekaragaman hayati. Fakultas Kehutanan IPB, Bogor.

Aswani S, Lauer M. 2006. Incorporating fishers' local knowlodge and behavior into geographical information systems (GIS) for designing marine protected areas in Oceania. Human Organization.

Aynalem, Y., and Afework, B. 2018. Diversity, distribution and habitat association of Birds in Menze-Guassa Community conservation area, Central Ethiopia. International Journal 
of Biodiversity and conservation.Vol. 10 (9). Pp. 372-379

Dede Hendry Triyanto. 2009. Laporan Skripsi. Persepsi, Motivasi, Sikap dan Perilaku Masyarakat Lokal Terhadap Keberadaan Hutan (Kasus di Kecamatan Gn. Kencana, Kabupaten Lebak, Propinsi Banten). Departemen Manajemen Hutan Fakultas Kehutanan Institut Pertanian Bogor. 2009

Departemen Kehutanan, Sub BKSDA 1995. Hasil survei permasalahan gangguan kawasan konservasi Taman Buru Pulau Moyo. Sub BKSDA Departemen Kehutanan, Kantor Wilayah Propinsi Nusa Tenggara Barat.

Departemen Kehutanan, BKSDA 2008. Hasil survei permasalahan gangguan kawasan konservasi Taman Nasional Lore Lindu. Departemen Kehutanan, Kantor Wilayah Propinsi Sualwesi Tengah.

Direktorat Jenderal Kehutanan, Direktorat Perlindungan dan Pengawetan Alam, 1988. Desain Pengelolaan dan Pengembangan Suaka Margasatwa Bali Barat. Laporan Penelitian Fakultas Kehutanan IPB Kerjasama dengan Direktorat Perlindungan dan Pengawetan Alam Departemen Kehutanan.

Edi Kartijono Nugroho, Margareta Rahayuningsih, dan Muhammad Abdullah. 2010. Vegetation Species Diversity and Bird Habitat Profi le of Pulau Nyamuk Mangrove Forest of Karimunjawa National Park. Biosaintifi ka Vol. 2 No.1, Maret 2010,ISSN 2085-191X, Hal 27-39.

Goth, A. and Vogel, U. 2004. Is Monogamy in the Polynesian Megapode (Megapodius Pritchardii) Related to its High Relative Egg-Weight?. American Ornithological Society. $\operatorname{pg}(\mathrm{s})$ 308-317.

Granados, C.P., Davies, E.S., Noguerales, V. 2018. Returning home after fire: how fire may help us manage the persistence of scrub-steppe specialist bird populations. Journal of Biodiversity and Conservation. Volume 27. pp 3087-3102 |

Harris,R.B., Birks,S.M., and Leache, A.D. 2014. Incubator birds ; biogeographical origins and evolution of underground nesting in megapodes (Galliformes: Megapodiidae).
Journal of Biogeography (J. Biogeogr) 2014) 4. pp 2045- 2056

Jessop, S., Joanna Sumner, M. Jeri Imansyah, Deni Purwandana, \& Aganto Seno 2006. Penilaian Distribusi, Penggunaan Musiman, dan Predasi Sarang Burung Gosong-kakimerah di Pulau Komodo. tjessop @zoo.org.au.

Kiky Arista, Abdul Wahid, Moh. Ihsan. 2015. Faktor Penyebab Penurunan Populasi Maleo Senkawor di Desa Sausu Piore Kabupaten Parigi Moutong Sulawesi Tengah. Warta Rimba Issn: 2406-8373 Volume 3, Nomor 2 Hal: 1-8 Desember 2015.

MacKinnon, J., K. Phillipps \& B. van Balen. 1992. Burung-burung di Sumatera, Jawa, Bali dan Kalimantan. Puslitbang Biologi LIPI, Jakarta.

Maria Rosdalima Panggur, 2008. Karakteristik Gundukan Bertelur dan Perilaku Bertelur Burung gosong kaki merah (Megapodius reinwardt Dumont 1823) di Pulau Rinca, taman nasional komodo. Skripsi, Departemen Konservasi Sumberdaya Hutan dan Ekowisata Fakultas Kehutanan Institut Pertanian Bogor. Maryadi, 1993. Fauna sebagai daya tarik wisatawan dan sumber devisa. Makalah dalam lokakarya teknologi konservasi fauna. Direktorat Teknologi Pemukiman dan Lingkungan Hidup, BPP Teknologi, Jakarta

Mujdalifah, Dwi K. Purnamasari, Abdul Aziz. Inventarisasi dan evaluasi nutrisi pakan burung gosong kaki merah (Megapodius reinwardt) pada pemeliharaan in-situ di Taman Wisata Alam Kerandangan. BioWallacea Vol. 2 No. 1, p. 42-47 Januari 2016.

Nathalie S.H., Badano. E.I, Torres, F.B, Flores,J., and Alvarez, C.P. 2018. Habitat suitability models to make conservation decisions based on areas of high species richness and endemism. Journal of Biodiversity and Conservation. Volume 27. pp 3185-3200

Sumiarsih Emi \& Yovita Hety Indriani, 1999. Melatih, memelihara, dan menangkar burung ocehan. Penebar Swadaya, Jakarta.

Yamin, M. dan Jamaluddin. 2003. Populasi dan Asosiasi Koak kao (Philemon buceroides) dengan Beberapa Jenis Tumbuhan pada 
habitatnya di Taman Buru Pulau Moyo, Nusa Tengga Barat. Biotropis Vol 2. Tahun 2003.

Yamin, I. Ny. Loka, dan I. Wy. Mertha., 2004. Studi kelangsungan hidup Koak kao (Philemon buceroides) di Taman Buru Pulau Moyo, Nusa Tengga Barat. Laporan penelitian Penguatan Riset Sains Dasar Bidang MIPA, Kementrian Riset dan Teknologi, Jakarta

Yamin \& I. Wy. Mertha., 2005. Studi pembiakan dan konservasi koak kao (Philemon buceroides) di Taman Buru pulau Moyo, Nusa Tengga Barat. Laporan penelitian
Penguatan Riset Sains Dasar Bidang MIPA, Kementrian Riset dan Teknologi, Jakarta

Yamin \& Lukman, 2008. Inseminasi buatan studi kelangsungan hidup koak kao (Philemon buceroides) sebagai upaya untuk mencegah kepunahannya.

Yamin \& Laksmiwati.,2012. Studi bioekologi, populasi dan kelangsungan hidup Burung gosong (Megapodius reinwardt) sebagai dasar konservasinya di habitat alam Pulau Moyo, Nusa Tengga Barat. Laporan penelitian Fundamental Bidang MIPA, Kementrian Pendidikan Nasional, Jakarta. 